\title{
The Impact of Work Environment and Compensation Toward Employee Performance (Case Study at PT. Hikari Teknologi Toolsindo)
}

\author{
Tri Wahju Wirjawan \\ Pelita Bangsa University, Indonesia \\ \{triwahyuwiryawan@pelitabangsa.ac.id\}
}

\begin{abstract}
This research aims to analyze the impact of the work environment and compensation on employee performance partially and together. The sampling technique uses random sampling, and data collection techniques in this research use a questionnaire. Instrument testing techniques in this study are the validity and reliability test, while the data analysis technique uses the classical assumption test, multiple linear regression analysis, and descriptive analysis. The results showed that employee performance. Partially the work environment has no impact on employee performance while compensation has an impact on performance.
\end{abstract}

Keywords: Work Environment, Compensation, Performance.

\section{Introduction}

Human resources as the main force to be able to make an organization become more developed, so that every organization or company is required to always pay attention to these aspects. Direct compensation is compensation directly received by employees consisting of salaries, transportation money, holiday allowances, overtime payments and other direct benefits. Indirect compensation is compensation that is not directly received by employees which consists of promotion of positions, insurance, benefits, and mutations (Hasibuan, 2010: 118). charged.

\section{Research Methods}

In this preparation the authors use a type of quantitative research, a method that emphasizes aspects of measurement objectively of social phenomena according to Siregar (2014: 130) data collection methods used in this study are as the research objects that support the the condition of the research object is compensation for employee performance.

\section{Results and Analysis}

Respondents based on Gender, it is known that the number of male respondents is 24 people 
or $48 \%$ while the rest are women 26 people or $52 \%$. Respondents based on Age, it is known that the number of respondents aged 18-25 years is as many as 15 people or $30 \%$, aged 26-33 years as many as 25 people or $50 \%$ and the remaining age of $34-45$ years as many as 10 people or $20 \%$. Respondents based on Education, it can be seen that the number of respondents with high school / vocational education is 40 people or $80 \%$ and S1 education is only 10 people or $20 \%$. Respondents based on Years of Service, it is known that the number of respondents with a working period of less than 6 months is 5 people or $10 \%, 1-2$ years working period of 25 people or $50 \%$ and the remaining $2-5$ years working period of 20 people or $40 \%$. The work environment $(\mathrm{X} 1)$ obtained the value of $\mathrm{r}$ table $=0.2353$, if the value of $\mathrm{r}$ count $=0.300$ compared to $r$ table, can be declared valid, because the value of $r$ count more than $r$ table. Compensation (X2) obtained the value of $r$ table $=0.2353$, if the value of $r$ count $=0.249$ compared to $r$ table, can be declared valid, because the value of $r$ count more than $r$ table. The alpha value of the calculation of the reliability variable compensation test is $0.774>0.600$, the Work Discipline variable is $0.655>0.600$, the Employee Performance variable is $0.684>0.600$ so the research instrument is declared reliable and can be used. The normality used in this study is the Kolmogorov-Smirnov OneSample Test, where the residual value is normally distributed if the sig value more than 0.05 . The output results from normality testing with Kolmogorov Smirnov obtained sig $=0,200$ more than 0.05 , meaning that the Unstandardized table is normally distributed. In the multicolliniarity test it is seen that each explanatory variable has a tolerance value more than 0.1 and a VIF value less than 10. So there is no multicollinearity between explanatory variables in this regression model. In the heteroscedasticity test showed explanatory variables have sig more than 0.05 . So the regression model does not contain heteroscedasticity. The multiple regression equation based on the analysis results can be found as follows: $\mathrm{Y}=6,415+0.402 \mathrm{X} 1+$ $0.370 \mathrm{X} 2$, Based on the F test, a Sig value of $0,000(\mathrm{p}>0.05)$ is obtained, meaning that the Work Environment (X1) and Compensation (X2) variables signifiantly influence jointly on Performance. The Sig value for the Work Environment (X1) on employee performance (Y) is $0.003<0.05$ and the $\mathrm{t}$ value is $3.153>\mathrm{t}$ table 2.011. so it can be concluded that $\mathrm{H} 1$ is accepted which means there is an impact of X1 on Y. 2. It is known that the Sig value for the impact of Compensation (X2) on Employee Performance (Y) is equal to $0.017<0.05$ and the value of $\mathrm{t}$ arithmetic $2.470>\mathrm{t}$ table 2.011, so it can concluded that $\mathrm{H} 2$ is accepted which means there is an impact of Work Discipline (X2) on Employee Performance (Y). Based on the dataobtained it is known that the significance value for the impact of the Work Environment (X1) and Compensation (X2) Simultaneously on Employee Performance (Y) is equal to $0,000<0.05$ and the calculated $\mathrm{F}$ value of $23.264>3.19$, so it can be concluded that $\mathrm{H} 3$ accepted which means there is an impact of Work Environment (X1) and Compensation (X2) simultaneously on employee performance (Y). The coefficient of determination results obtained by 0.497 . This indicates that $49.7 \%$ of work environment and compensation affect employee performance while the remaining $50.3 \%$ of employee performance is affected by other factors not examined in this research.

\section{Conclusion}

a) Results Hypothesis testing has proven that the Work Environment has a positive impact on employee performance. This means that there is a partial impact between the Compensation on employee performance.

b) Hypothesis testing results have proven there is an correlation between Compensation on employee performance. This means that partially there is an correlation between the Work 
Discipline on employee performance . Based on the results of the calculation of the Work Environment and Compensation the hypothesis is that each change / increase jointly between the compensation and Work Discipline affects the level of employee performance.

\section{References}

[1] Amir, Pengaruh Kepemimpinan, Kompensasi dan kedisiplinan terhadap kinerja karyawan magang dipuskesmas mangkoso kabupaten barru dijurnal of Management : Volume 1, Nomor 3, Tahun 2018

[2] Aromega Tanod Nanda, Pengaruh kompensasi dan disiplin kerja terhadap kinerja karyawan Yuta Hotel Manado ISSN 741-750Emba journal: volume 7 (2019).

[3] Bangun, 2012.Manajemen Sumber Daya Manusia. Jakarta:Erlangga.

[4] Hasibuan.2010.Manajemen Sumber Daya Manusia Edisi Revisi. Jakarta: Bumi Aksara.

[5] Mangkunegara.2012.Evaluasi Sumber Daya Manusia. Bandung: Refika Aditama.

[6] Mangkunegara.2012.Manajemen Sumber Daya Manusia Perusahaan. Bandung:

[7] Maharani Intan, Pengaruh Budaya Organisasi, komitmen organisasi,kompensasi,dan etos kerja terhadap kinerja pegawai kementerian ketenagakerjaan republic indonesia Journal Ilmu manajemen Vol. 13, No. 2: juli 2017

[8] Marthis, L. R., Jackson, H. J.2009.Human Resource Manajemen (Manajemen Sumber Daya Manusia).Jakarta: Salemba Empat

[9] Novita N, Pengaruh Motivasi,Disiplin Kerja,Kepemimpinan dan Kompensasi terhadap kinerja pegawai PT Adidayah tangguh dikabupaten pulau tali abu terbit dijurnal Emba : Volume 5, Nomor 3, September 2017.

[10] Purnama Catherine, Pengaruh kompensasi dan disiplin kerja terhadap kinerja karyawan Cv. Cahaya Citra Surya Indoprimadijurnal Agora : Volume 2, Nomor 4, 2016

[11] Rivai dan Sagala, 2009.Manjemen Sumber Daya Manusia Untuk Perusahaan Dari Teori KePraktik. Jakarta: Raja Grafindo

[12] Setiawan, A.2013.Pengaruh Disiplin Kerja dan Motivasi Terhadap Kinerja Karyawan pada Rumah Sakit Umum Daerah Kanjuruhan Malang.Jurnal Ilmu Manajemen.

[13] Sinambela, L.P.2016.Manjaemen Sumber Daya Manusia Membangun Tim Kerja yang Solid untuk Meningkatkan Kinerja.Jakarta: Bumi Aksara

[14] Siregar,S.2014.Statistik Deskriptif Untuk Penelitian.Jakarta: Rajawali Pers.

[15] Sutrisno .2009.Manajemen Sumber Daya Manusia.Jakarta: Kencana. 